\title{
Fast Detection of Auxins by Microplate Technique
}

\section{Julia Cecilia Anguiano-Cabello, Alberto Flores-Olivas*, Yisa María Ochoa-Fuentes, Roberto Arredondo-Valdés, Victor Olalde-Portugal}

Department of Parasitology, Antonio Narro Agrarian Autonomous University, Saltillo, Mexico

Email: *julia_c922@hotmail.com

How to cite this paper: Anguiano-Cabello, J.C., Flores-Olivas, A., Ochoa-Fuentes, Y.M., Arredondo-Valdés, R. and Olalde-Portugal, V. (2017) Fast Detection of Auxins by Microplate Technique. American Journal of Plant Sciences, 8, 171-177.

http://dx.doi.org/10.4236/ajps.2017.82013

Received: November 30, 2016

Accepted: January 17, 2017

Published: January 20, 2017

Copyright (c) 2017 by authors and Scientific Research Publishing Inc. This work is licensed under the Creative Commons Attribution International License (CC BY 4.0).

http://creativecommons.org/licenses/by/4.0/

\begin{abstract}
Plant growth promotion indole-3-acetic acid (IAA) is the most abundant natural auxin that plays diverse roles in plant growth, development and plant immunity. Perturbing auxin homeostasis appears to be a common virulence mechanism, as many pathogens can synthesize auxin-like molecules. In other hand, the addition of plant growth promotion rhizobacteria (PGPR) that are able to produce auxins promotes plant growth and provides protection against pathogens. Techniques as high performance liquid chromatography (HPLC) and gas chromatography (GC) are used to quantify auxins produced by microorganism and plants at high precision and sensitivity, even though those techniques are expensive and require a big number of solvents. For these reasons, the aim of the present study was to develop a fast microplate technique for auxin detection, in Bacillus subtilis strains using salkowski reagent. For auxin quantification, calibration curves were done with alcohol, landy medium and water and the $\mathrm{R}^{2}$ were calculated. The microplate techniques were able to quantify auxin production by $B$. subtillis stains.
\end{abstract}

\section{Keywords}

Auxin, Microplate, Bacillus subtilis

\section{Introduction}

Plant hormones have pivotal roles in the regulation of plant growth, development, and reproduction [1]. Additionally, they emerged as cellular signal molecules with key functions in the regulation of immune responses to microbial pathogens, insect herbivores, and beneficial microbes [1]. Recent studies indicate that hormones such as abscisic acid (ABA), auxin, gibberellic acid (GA), cytokinin (CK), brassinosteroids (BR) and peptide hormones are implicated in plant defense signaling pathways [2]. In other hand, beside the endogenous produc- 
tion of phytohormones, exogenous phytohormones can be provided by plant growth-promoting rhizobacteria (PGPR) [3] [4]. The PGPR produces hormones such as auxins, gibberellins, cytokinins and polyamines [3]. Auxin is an important plant hormone that affects almost all aspects of plant growth and development and immunity [5]. Perturbing auxin homeostasis appears to be a common virulence mechanism, as many pathogens can synthesize auxin-like molecules [5]. This way, the addition of PRGR producers of auxins promotes plant growth and provides protection against pathogens. Bacillus sp., Bacillus subtilis, Mycobacterium sp. and Pseudomonas putida are examples of auxin producers [4] [6] [7] [8] [9] [10]. The discovery and study of PGPR require fast and reliable methods for quantifying phytohormones. For auxin and indoles detection, techniques are used such as high performance liquid chromatography (HPLC) [3], thin layer chromatography (TLC) [11] and spectrophotometric techniques with salkowski reagent [12]. Even though these techniques are expensive because of the use of columns and solvents (HPLC) or are not practical for processing big quantity of samples at the same time (TLC). The aim of this study was to develop a microplate method for quantifying auxins, with less number of reagents, and for processing more samples in fewer time. For auxin quantification, calibration curves were realized using 3 -indol acetic acid (IAA) dissolved in water, Landy medium or alcohol, and using salkowski reagent. The microplate techniques developed were used to quantify auxins in Bacillus subtilis fermentation broths proved previously as auxin producers.

\section{Materials and Methods}

\subsection{Bacterial Strains and Fermentation Conditions}

Three Bacillus subtillis strains were evaluated. BSN strain was obtained from Cinvestav Irapuato. BS8 and BS14 strains were gotten from Phytophatology department from the Antonio Narro Agrarian Autonomous University. Fermentation was realized in landy medium added with tryptophan. Landy medium was prepared as follow: glutamic acid $5.0 \mathrm{~g} / \mathrm{L}, \mathrm{KH}_{2} \mathrm{PO}_{4} 0.5 \mathrm{~g} / \mathrm{L}, \mathrm{K}_{2} \mathrm{HPO}_{4} 0.5 \mathrm{~g} / \mathrm{L}$, $\mathrm{MgSO}_{4} \cdot 7 \mathrm{H}_{2} \mathrm{O} 0.2 \mathrm{~g} / \mathrm{L}, \mathrm{MnSO}_{4} \cdot \mathrm{H}_{2} \mathrm{O} 0.01 \mathrm{~g} / \mathrm{L}, \mathrm{NaCl} 0.01 \mathrm{~g} / \mathrm{L}, \mathrm{FeSO}_{4} \cdot 7 \mathrm{H}_{2} \mathrm{O} 0.01 \mathrm{~g} / \mathrm{L}$, $\mathrm{CuSO}_{4} \cdot 7 \mathrm{H}_{2} \mathrm{O} 0.01 \mathrm{~g} / \mathrm{L}, \mathrm{CaCl}_{2} \cdot 2 \mathrm{H}_{2} \mathrm{O} 0.015 \mathrm{~g} / \mathrm{L}$ and tryptophan (final concentration $5 \mathrm{mM}$ ). A solution of glucose microfiltrated was added to the medium for a final concentration of $1 \%$. A preinoculum was realized by inoculation in $50 \mathrm{~mL}$ of landy medium, incubated $48 \mathrm{~h}$ at $28^{\circ} \mathrm{C}$. From preinoculum were prepared the fermentation broths at a concentration of $1 \times 10^{7} \mathrm{CFU} / \mathrm{mL}$ in Landy medium, and were shaken for $72 \mathrm{~h}, 120 \mathrm{rpm}$ and $25^{\circ} \mathrm{C}$ [13]. The fermentation broths were centrifugated at $12,500 \mathrm{rpm}$ for $15 \mathrm{~min}$ and $15^{\circ} \mathrm{C}$ to get the supernatant for quantifying auxins [14] [15].

\subsection{Auxins Quantification}

Salkowski reagent was prepared as follow: $15 \mathrm{~mL}$ of $\mathrm{H}_{2} \mathrm{SO}_{4}, 25 \mathrm{~mL}$ of distilled water, $0.75 \mathrm{~mL}$ of $\mathrm{FeCl}_{3} \cdot 6 \mathrm{H}_{2} \mathrm{O}(0.5 \mathrm{M})$ [16]. For calibration curves were prepared stocks of 3-indol acetic acid (IAA) at concentration of 100,000 ppm in ethanol. 
And work solutions at 16,000 ppm in water, ethanol and or Landy medium [17]. For calibration curve were placed in all a row of the microplate $100 \mu \mathrm{L}$ of the dissolvent (Landy medium, water or ethanol), and then in the first line were added $100 \mu \mathrm{L}$ of $16,000 \mathrm{ppm}$ work solutions, for get a first point in the calibration curve of $8000 \mathrm{ppm}$. It is mixed and $100 \mu \mathrm{L}$ are taken to the second line (4000 ppm), then mixed and $100 \mu \mathrm{L}$ are taken to the third line $(2000 \mathrm{ppm})$. This procedure is followed until the line 11 [18] [19] [20]. The line 12 is the concentration 0 ppm. $100 \mu \mathrm{L}$ of salkowski reagent are added to every well, incubated for $30 \mathrm{~min}$ and read at $520 \mathrm{~nm}$ [9] [16] [21]. Each curve was performed by triplicate.

The concentration of IAA in Bacillus subtilis strains was evaluated in microplate as follow: $100 \mu \mathrm{L}$ of cell free supernatant were mixed with $100 \mu \mathrm{L}$ of salkowski reagent in the microplate, incubated for $30 \mathrm{~min}$ and read at $520 \mathrm{~nm}$. After, the auxin concentrations in supernatants were calculated using the calibration curve equation with the higher $\mathrm{R}^{2}$.

\section{Results and Discussion}

The purple-pink complexes were observed in the microplate formed by the IAA and the salkowski reagent. $\mathrm{R}^{2}$ were gotten from calibration curves and indicates the lineality in the evaluated range. At lower concentration range the $\mathrm{R}^{2}$ was higher than at higher concentration. Each solvent presented different linearity. Since IAA dissolves better in alcohol the lineality with ethanol is higher than in other solvents (Table 1).

Auxins concentrations in samples were calculated using the calibration curve with ethanol from 0 to $31.25 \mathrm{ppm}$, which had the higher $\mathrm{R}^{2}$. The auxins concentration calculated for the Bacillus subtilis strains was $2.78 \mathrm{ppm}$ for BS8, $2.59 \mathrm{ppm}$ for BS14 and $18.59 \mathrm{ppm}$ for BSN. The detection of auxins in Bacillus subtilis strains probed that they are able to promote plant growth and they can elicit significant reductions in the incidence or severity of various diseases on a diversity of hosts [22].

Over the years, large efforts have been put in the development of more sensitive and precise methods of analysis and quantification of plant hormone levels in plant tissues and microorganisms. However, although the techniques have evolved, and new methods have been implemented, the sample preparation is still the limiting step of auxin analysis, including extraction, purification and derivatization [23]. The quantification of auxins by salkowski reagent doesn't need an exhaustive sample preparation. It only requires the separation of the super-

Table 1. Solvents, concentration range, $\mathrm{R}^{2}$ and calibration curves equations in auxins calibration curves.

\begin{tabular}{cccc}
\hline Solvent & Concentration range & $\mathrm{R}^{2}$ & Calibration curves equations \\
\hline Alcohol & $0-2000 \mathrm{ppm}$ & 0.93 & $\mathrm{y}=0.0014 \mathrm{x}+0.3191$ \\
Alcohol & $0-31.25 \mathrm{ppm}$ & 0.99 & $\mathrm{y}=0.0107 \mathrm{x}-0.0032$ \\
Landy medium & $0-2000 \mathrm{ppm}$ & 0.94 & $\mathrm{y}=0.0012 \mathrm{x}+0.2209$ \\
Water & $0-4000 \mathrm{ppm}$ & 0.80 & $\mathrm{y}=0.0005 \mathrm{x}+0.576$ \\
\hline
\end{tabular}


natant by centrifugation after the fermentation time. Even though, the salkowski reagent is not specific for only one type of auxin. The principal auxin detected by salkowski reagent is the IAA but other auxins can also form complex with the reagent. Glickmann and Dessaux [24] demonstrated that the production of Salkowski positive compounds, even at low concentrations, was always correlated with production of IAA or indolepyruvic acid (IPyA). For these reasons the microplate technique should be complement with other technique as chromatography, if the study needs to quantify a specific auxin.

The developed microplate methods show advantages as analysis of large numbers of samples in a short time with low cost. Even GC-MS is technically the best method to measure IAA, because of high sensitivity and specificity [25] [26], the high cost for setting and maintenance makes it difficult for daily use in ordinary laboratory [25]. The range of lineality of the microplate technique with ethanol and a $\mathrm{R}^{2}$ of 0.99 is low related to the studies of Szkop in 2013 [27] who quantified by RP-HPCL samples containing indolic compounds at $0.0625-125$ ppm, using calibration curves with coefficient of determination $\left(R^{2}\right) \geq 0.998$, even though samples can be diluted for making an approximation of auxin concentration by microplate technique before using another technique. Meanwhile, Kim and Park [25] established a standard method to quantify IAA based on HPLC, adopting fluorescence detector and Indole-3-propionic acid (IPA) as internal standard and calculated the IAA concentration with the peak area. A microplate method for auxins was realized by Sarwar and Kremer in 1995 [28], were resulted in $95 \%$ less sample and reagent volume and it was faster than the traditional method, since the standard method required each sample by separately. They realized a calibration curve with 6 points from 0 to 40 IAA equivalents (ppm), but it does not specify the solvent where it is realized. Alcohol calibration curves with ethanol got a higher $\mathrm{R}^{2}$ because of the IAA solubility properties. Even though it's important realize calibration curves with other solvents because most of fermentations broths are colorful and it could interference with the UV spectrometer absorbance. Landy medium, a specific medium enriched with tryptophan for auxin production, presented a different color to the salkowski reagent but is still colorful. For this reason, colorless mediums for auxin production must be developed for colorimetric techniques.

The developed method could be used also to quantify auxins production in plants. However, because hormones production occur in very low amounts in plant extracts, and are very rich in interfering substances, especially secondary metabolites, must undergo several purification steps using unrelated separation mechanisms in order to increase purification efficiency. And especially it is important to know which part of the plant contains the highest concentration of auxin. Generally auxins are produced in the meristematic areas of the plant stem although other plant parts, for instance, shoots, roots and leaves may also produce auxins [29]. Auxin concentration varies depending on the influx and efflux from the tissues, its biosynthesis from tryptophan and formation of IAA conjugates [30]. The homeostasis between the endogenous and exogenous auxins 
contribute in the plant developed and immunology, for these reason the quantification of auxins produced by PGPR is important to select the strain with the right production of phytohormones.

\section{Acknowledgements}

This research was financial by the Antonio Narro Autonomous Agrarian University.

\section{References}

[1] Pieterse, C.M., Van der Does, D., Zamioudis, C., Leon-Reyes, A. and Van Wees, S.C. (2012) Hormonal Modulation of Plant Immunity. Annual Review of Cell and Developmental Biology, 28, 489-521. https://doi.org/10.1146/annurev-cellbio-092910-154055

[2] Bari, R. and Jones, J.D. (2009) Role of Plant Hormones in Plant Defence Responses. Plant Molecular Biology, 69, 473-488. https://doi.org/10.1007/s11103-008-9435-0

[3] Fernandes, G.R., Aparecida, N.P., Luque, C.T. and De Macedo, L.E. (2011) AuxinProducing Bacteria Isolated from the Roots of Cattleya walkeriana, an Endangered Brazilian Orchid, and Their Role in Acclimatization. Revista Brasileira de Ciência do Solo, 35, 729-737. https://doi.org/10.1590/S0100-06832011000300008

[4] Ahemad, M. and Kibret, M. (2014) Mechanisms and Applications of Plant Growth Promoting Rhizobacteria: Current Perspective. Journal of King Saud UniversityScience, 26, 1-20.https://doi.org/10.1016/j.jksus.2013.05.001

[5] Spoel, S.H. and Dong, X. (2008) Making Sense of Hormone Crosstalk during Plant Immune Responses. Cell Host \& Microbe, 3, 348-351. https://doi.org/10.1016/j.chom.2008.05.009

[6] Pandey, A., Trivedi, P., Kumar, B. and Palni, L.M.S. (2006) Characterization of a Phosphate Solubilizing and Antagonistic Strain of Pseudomonas putida (B0) Isolated from a Sub-Alpine Location in the Indian Central Himalaya. Current Microbiology, 53, 102-107. https://doi.org/10.1007/s00284-006-4590-5

[7] Parani, K. and Saha, B.K. (2012) Prospects of Using Phosphate Solubilizing Pseudomonas as bio Fertilizer. European Journal of Biological Sciences, 4, 40-44.

[8] Dey, R., Pal, K.K., Bhatt, D.M. and Chauhan, S.M. (2004) Growth Promotion and Yield Enhancement of Peanut (Arachis hypogaea L.) by Application of Plant Growth-Promoting Rhizobacteria. Microbiological Research, 159, 371-394. https://doi.org/10.1016/j.micres.2004.08.004

[9] Wahyudi, A.T., Astuti, R.P., Widyawati, A., Meryandini, A. and Nawangsih, A.A. (2011) Characterization of Bacillus sp. Strains Isolated from Rhizosphere of Soybean Plants for Their Use as Potential Plant Growth for Promoting Rhizobacteria. Journal of Microbiology and Antimicrobials, 3, 34-40.

[10] Solís, D.R., Pérez, M.C. and Santoyo, G. (2014) Mechanisms for Estimating Plant Growth for Bacteria of the Genus Bacillus. Mecanismos de estimulación del crecimiento vegetal en bacterias del género Bacillus. Biological Journal of the Biological science Michoacana University of San Nicolas of Hidalgo, 15, 36-41.

[11] Castillo, G., Ortega, G., Carabeo, V., Delgado, G. and Michelena, G. (2007) Determinación cualitativa de giberelinas y auxinas por cromatografía de capa fina. ICIDCA. Sobre los Derivados de la Caña de Azúcar, 41, 12-17. http://www.redalyc.org/articulo.oa?id=223114967002

[12] Cubillos, J.R., Castellanos, D.E. and Argüello, H. (2009) Selección de Microorganismos Promotores de Crecimiento Vegetal (Ácido Indol Acético) a partir de $\mathrm{Mu}$ - 
estras de Suelo Rizosferico, como Primera Etapa en el Desarrollo de un Biofertilizante. Journal Brasileira de Agroecología, 4.

[13] Awais, M., Pervez, A., Yaqub, A. and Shah, M.M. (2010) Production of Antimicrobial Metabolites by Bacillus subtilis Immobilized in Polyacrylamide Gel. Pakistan Journal of Zoology, 42, 267-275.

[14] Sayyed, R.Z., Badgujar, M.D., Sonawane, H.M., Mhaske, M.M. and Chincholkar, S.B. (2005) Production of Microbial Iron Chelators (Siderophores) by Fluorescent Pseudomonads. Indian Journal of Biotechnology, 4, 484-490. http://nopr.niscair.res.in/handle/123456789/5776

[15] Yu, X., Ai, C., Xin, L. and Zhou, G. (2011) The Siderophore-Producing Bacterium, Bacillus subtilis CAS15, Has a Biocontrol Effect on Fusarium Wilt and Promotes the Growth of Pepper. European Journal of Soil Biology, 47, 138-145. https://doi.org/10.1016/j.ejsobi.2010.11.001

[16] Gordon, S.A. and Weber, R.P. (1951) Colorimetric Estimation of Indoleacetic Acid. Plant Physiology, 26, 192-195. https://doi.org/10.1104/pp.26.1.192

[17] Mata, N.M. and Méndez-Natera, J.R. (2009) Effect of Indole-3-Acetic Acid and Naphthaleneacetic Acid on the Length and Width of Melon Fruit (Cucumismelo L.) Edisto 47. Journal Científica UDO Agrícola, 9, 530-538.

[18] Mdee, L.K., Masoko, P. and Eloff, J.N. (2009) The Activity of Extracts of Seven Common Invasive Plant Species on Fungal Phytopathogens. South African Journal of Botany, 75, 375-379. https://doi.org/10.1016/j.sajb.2009.02.003

[19] Kouassi, K.H.S., Bajji, M., Brostaux, Y., Zhiri, A., Samb, A., Lepoivre, P. and Jijakli, H. (2012) Development and Application of a Microplate Method to Evaluate the Efficacy of Essential Oils against Penicillium italicum Wehmer, Penicillium digitatum Sacc. and Colletotrichum musea (Berk. \& M.A. Curtis) Arx, Three Postharvest Fungal Pathogens of Fruits. Biotechnology, Agronomy, Society and Environment, $16,325-336$.

[20] Calvo, P. and Zúñiga, D. (2010) Physiological Characterization of Bacillus spp. Strains from Potato (Solanum tuberosum). Ecología Aplicada, 9, 31-39.

[21] Abdel-Aziz (2013) Extracellular Metabolites Produced by a Novel Strain, Bacillus alvei NRC-14:5. Multiple Plant-Growth Promoting Properties. Journal of Basic and Applied Scientific Research, 3, 670-682.

[22] Kloepper, J.W., Ryu, C.M. and Zhang, S. (2004) Induced Systemic Resistance and Promotion of Plant Growth by Bacillus spp. Phytopathology, 94, 1259-1266. https://doi.org/10.1094/PHYTO.2004.94.11.1259

[23] Porfírio, S., da Silva, M.D.G., Peixe, A., Cabrita, M.J. and Azadi, P. (2016) Current Analytical Methods for Plant Auxin Quantification-A Review. Analytica Chimica Acta, 902, 8-21. https://doi.org/10.1016/j.aca.2015.10.035

[24] Glickmann, E. and Dessaux, Y. (1995) A Critical Examination of the Specificity of the Salkowski Reagent for Indolic Compounds Produced by Phytopathogenic Bacteria. Applied and Environmental Microbiology, 61, 793-796.

[25] Kim, Y.J., Oh, Y.J. and Park, W.J. (2006) HPLC-Based Quantification of Indole-3-Acetic Acid in the Primary Root Tip of Maize. Journal of Nanobiotechnolo$g y, 3,40-45$.

[26] Idris, E.E., Iglesias, D.J., Talon, M. and Borriss, R. (2007) Tryptophan-Dependent Production of Indole-3-Acetic Acid (IAA) Affects Level of Plant Growth Promotion by Bacillus amyloliquefaciens FZB42. Molecular Plant-Microbe Interactions, 20, 619-626. https://doi.org/10.1094/MPMI-20-6-0619

[27] Szkop, M. and Bielawski, W. (2013) A Simple Method for Simultaneous RP-HPLC 
Determination of Indolic Compounds Related to Bacterial Biosynthesis of Indole-3-Acetic Acid. Antonie van Leeuwenhoek, 103, 683-691. https://doi.org/10.1007/s10482-012-9838-4

[28] Sarwar, M. and Kremer, R.J. (1995) Determination of Bacterially Derived Auxins Using a Microplate Method. Letters in Applied Microbiology, 20, 282-285. https://doi.org/10.1111/j.1472-765X.1995.tb00446.x

[29] Ahmed, A. and Hasnain, S. (2014) Auxins as One of the Factors of Plant Growth Improvement by Plant Growth Promoting Rhizobacteria. Polish Journal of Microbiology, 63, 261-266.

[30] Tanimoto, E. (2005) Regulation and Root Growth by Plant Hormones-Roles for Auxins and Gibberellins. Critical Reviews in Plant Sciences, 24, 249-265.

https://doi.org/10.1080/07352680500196108

Submit or recommend next manuscript to SCIRP and we will provide best service for you:

Accepting pre-submission inquiries through Email, Facebook, LinkedIn, Twitter, etc. A wide selection of journals (inclusive of 9 subjects, more than 200 journals) Providing 24-hour high-quality service User-friendly online submission system Fair and swift peer-review system Efficient typesetting and proofreading procedure Display of the result of downloads and visits, as well as the number of cited articles Maximum dissemination of your research work

Submit your manuscript at: http://papersubmission.scirp.org/

Or contact ajps@scirp.org 